\title{
INDEKS STABILITAS AGREGAT TANAH PADA PERKEBUNAN TEH BERBASIS SLOPE DAN UMUR TANAMAN DI KECAMATAN GUNUNG TALANG KABUPATEN SOLOK
}

\section{Soil Aggregate Stability Index in Tea Plantation Based on Slopes and Crop Ages in Gunung Talang, Solok}

\author{
Dendy Detafiano Prakasa Afner*, Aprisal, Yulnafatmawita \\ Program Studi Ilmu Tanah, Fakultas Pertanian, Universitas Andalas, Limau Manis, Padang, 25163 \\ *Penulis korespondensi: dendyafner@gmail.com
}

\begin{abstract}
Land-use change from the forest into tea plantation in Solok Regency in 1983 has decreased the area of forests in Gunung Talang District. Clearing up the forest at the beginning for tea plantation could worsen the physical and chemical conditions of the soil. One of which is soil aggregate stability that is very dynamic and can influence other soil physical properties. This study was aimed to determine soil Aggregate Stability Index (ASI) at tea plantations. Soil samples was taken at a depth of $0-20 \mathrm{~cm}$ from five different slopes (0-8\% (A), $8-15 \%$ (B), $15-25 \%$ (C), $25-45 \%$ (D), and $>$ $45 \%$ (E)) and at two crop ages (10 and 35 years old). The results showed that the soil aggregate stability index at tea plantations ranged from stable to very stable. It tended to decrease by increasing slope percentage at each of crop age, Between the ages, it showed higher ASI at 35 years old crop age under relatively flat $(0-8 \%)$ and very steep $(>45 \%)$ areas.
\end{abstract}

Keywords: aggregate stability index, crop age, slope level, soil structure, tea plantation

\section{Pendahuluan}

Pertanian khususnya bidang perkebunan berkembang sangat pesat pada beberapa dekade terakhir ini di Indonesia. Perluasan areal perkebunan dan pertanian dengan mengkonversi lahan hutan telah mengganggu keseimbangan alam dan menyebabkan kerusakan pada tanah sehingga akan berdampak buruk bagi lingkungan dan kehidupan manusia ke depannya. Efek samping dari kegiatan alih fungsi lahan ini adalah rusaknya struktur tanah yang akan berujung pada bencana alam seperti banjir, longsor, erosi berlebihan, dan berbagai macam kerusakan lainnya yang akan saling berkaitan.

Struktur tanah merupakan hal yang sangat penting untuk dijaga keadaannya, karena struktur tanah sangat mempengaruhi porositas dan infiltrasi tanah serta menahan air agar selalu tersedia bagi tanaman (Six et al., 2000). Salah satu hal yang akan sangat mempengaruhi keadaan struktur tanah adalah bahan organik tanah. Bahan organik akan memberikan struktur tanah yang remah dan aggregat yang mantap. Tanah dengan bahan organik yang tinggi mempunyai pori tanah yang seimbang antara pori makro yang melewatkan air dan mikro yang menahan air dalam tanah. Seperti yang dilaporkan oleh Fitter dan Hay (1998), bahan organik akan melapuk dan menciptakan humus yang memiliki kemampuan mengikat air hingga 6 kali lipat bobotnya sendiri sehingga penguapan akan berkurang. Dengan demikian, air dan udara tersedia bagi kebutuhan pertumbuhan tanaman, laju infiltrasi terjaga sehingga runoff bisa dikurangi dan kemungkinan erosi bisa diantisipasi.

Lahan hutan yang belum terganggu selama ini telah menyediakan bahan organik secara terus menerus bagi tanah sehingga keseimbangan alam terjaga dan kecil kemungkinan terjadinya bencana di sekitar 


\section{Jurnal Tanah dan Sumberdaya Lahan Vol 8 No 1: 75-81, 2021 \\ e-ISSN:2549-9793, doi: 10.21776/ub.jts1.2021.008.1.10}

kawasan hutan. Keinginan untuk meningkatkan taraf hidup membuat manusia mengeksploitasi lahan hutan secara besar-besaran. Aktifitas tersebut cenderung tidak memperhatikan kaidah konservasi sehingga menyebabkan degradasi lahan dan lingkungan. Konversi lahan hutan yang cukup luas umumnya diperuntukan bagi perkebunan kelapa sawit dan juga teh.

Teh adalah salah satu komoditi perkebunan yang pengelolaannya cukup luas di Indonesia dan berumur panjang. Kondisi bentang alam Indonesia yang baik membuat tanaman teh dapat tumbuh dengan subur. Teh adalah tanaman subtropis yang dapat hidup optimal pada suhu udara berkisar $13^{0}-15^{\circ} \mathrm{C}$ dan kelembaban relatif $>70 \%$ pada siang hari, sehingga teh cocok dibudidayakan di daerah pegunungan (BPPP, 2010). Syarat tumbuh tanaman teh yang menghendaki keadaan curah hujan 2000-2500 mm membuat tanaman ini dapat tumbuh dengan baik di daerah Kabupaten Solok khususnya Kecamatan Gunung Talang yang memiliki curah hujan rata-rata $3087,5 \mathrm{~mm} /$ tahun. Pada umumnya teh diusahakan di daerah dataran tinggi dengan kondisi slope yang landai sampai sangat curam $(>45 \%)$.

Pembudidayaan tanaman pada daerah lereng pegunungan akan beresiko meningkatkan nilai kerusakan lahan akibat pengelolaan dan pengolahan tanah selama budidaya tanaman. Akan tetapi, tanaman teh adalah tanaman pertanian yang tidak memerlukan pengolahan tanah yang intensif di dalam pembudidayaannya. Seperti yang telah dilaporkan oleh Wachjar dan Rohmah (2015) pemangkasan pada tanaman teh bertujuan untuk meningkatkan produktivitas tanaman serta akan mempermudah proses pemetikan. Junaedi dan Safitri (2018) juga menambahkan bahwa bagian yang dapat dipanen dan bernilai ekonomi dari tanaman teh adalah pucuk atau daun teh muda. Oleh karena itu keadaan tanaman teh sangat mempengaruhi produksi, baik jumlah maupun kualitas pucuk yang dihasilkan. Sistem pemangkasan yang dilakukan selama pembudidayaan tanaman teh akan menyumbangkan bahan organik dalam jumlah yang banyak, dan akan membantu dalam memperbaiki kondisi fisik tanah di perkebunan teh. Semakin lama umur tanaman teh, maka semakin banyak pula residu tanaman yang tertumpuk di permukaan tanah yang menjadi sumber bahan organik utama bagi tanah.

Bahan organik di dalam tanah akan mempengaruhi stabilitas agregat tanah Stabilitas agregat tanah merupakan salah satu indikator dalam mengukur tingkat degradasi lahan. Meningkatnya stabilitas agregat tanah akan berdampak baik bagi sifat fisika tanah lain seperti total ruang pori, aerase dan drainase tanah, infiltrasi, dan permeabilitas tanah. Selain itu, tingkat kepekaan tanah terhadap laju erosi juga akan menurun pada tanah dengan aggregate yang mantap (Kurnia, 1996). Penelitian ini bertujuan untuk mengetahui nilai indeks stabilitas agregat tanah pada perkebunan teh berbasis slope dan umur tanaman teh.

\section{Bahan dan Metode}

\section{Lokasi penelitian}

Penelitian telah dilaksanakan pada bulan Juli 2019 hingga bulan Desember 2019 di perkebunan teh rakyat yang berlokasi di Kecamatan Gunung Talang, Kabupaten Solok. Secara geografis lokasi penelitian berada diantara $00^{\circ} 58^{\prime} 19,261$ " LS sampai $01^{0} 1^{\prime}$ 19,158" LS dan $100^{\circ} 36^{\prime}$ '27,089" BT sampai $100^{\circ} 39^{\prime} 32,728^{\prime \prime}$ BT. Lokasi penelitian berada pada ketinggian $1195 \mathrm{~m}$ d.p.l dan memiliki topografi datar hingga berbukit. Curah hujan rata-rata per bulan berkisar $110-524 \mathrm{~mm}$, dan data curah hujan delapan tahun terakhir menunjukkan rata-rata curah hujan yaitu 3087,5 $\mathrm{mm}$ tahun $^{-1}$. Perkebunan teh yang dijadikan sebagai lokasi pengambilan sampel adalah perkebunan teh yang telah berumur 10 dan 35 tahun. Sampel tanah juga diambil di hutan sekunder yang berdekatan dengan perkebunan teh ini untuk digunakan sebagai kontrol.

\section{Pelaksanaan penelitian}

Sampel tanah beragregat utuh diambil pada kedalaman $0-20 \mathrm{~cm}$ dengan menggunakan cangkul di setiap slope (0-8\% (A), $8-15 \%$ (B), $15-25 \%$ (C), $25-45 \%$ (D), dan $>45 \%$ (E)). Sampel tanah beragregat utuh dimasukkan ke dalam plastik sampel ukuran $5 \mathrm{~kg}$ untuk lalu ditempatkan di dalam kotak plastik agar agregat tanah tidak hancur selama proses pemindahan dari lapangan ke laboratorium. Selanjutnya, 


\section{Jurnal Tanah dan Sumberdaya Lahan Vol 8 No 1: 75-81, 2021 \\ e-ISSN:2549-9793, doi: 10.21776/ub.jts1.2021.008.1.10}

sampel tanah beragregat utuh dikeringanginkan selama \pm 1 minggu. Analisis tanah dilaksanakan di laboratorium tanah, jurusan Ilmu Tanah Fakultas Pertanian, Universitas Andalas Padang. Parameter yang diukur meliputi stabilitas agregat tanah menggunakan metode $d r y$ and wet sieving, C-Organik menggunakan metode Walkley and Black, Berat Volume tanah menggunakan metoda Gravimetri, dan Tekstur tanah menggunakan metoda Pipet dan Ayakan.

\section{Hasil dan Pembahasan}

\section{Tekstur, berat volume, dan total ruang pori tanah}

Perkebunan teh di Kecamatan Gunung Talang memiliki luas 336,15 ha dari total 443 ha perkebunan teh rakyat yang ada di Kabupaten Solok. Tanah di daerah ini tergolong ordo
Inceptisol menurut peta tanah Pusat Penelitian Tanah dan Agroklimatologi (1990). Inceptisol merupakan tanah yang belum berkembang lanjut dengan ciri bersolum tebal $1.5-10 \mathrm{~m}$ di atas bahan induk, bertekstur liat, dan memiliki struktur yang lemah dan konsistensi tanah yang gembur.

Hasil analisis di laboratorium menunjukkan kelas tekstur tanah pada daerah penelitian memiliki tekstur yang halus dan sedang seperti liat, lempung berdebu, dan liat berdebu. Menurut Resman et al., (2006) tanah yang memiliki tekstur seperti ini memiliki kemampuan pegang air dan unsur hara yang baik. Yulnafatmawita et al. (2007) juga menambahkan tanah berordo Inceptisol didominasi oleh pisahan tanah yang halus dengan persentase kandungan liat lebih tinggi dibandingkan dengan persentase debu dan pasir.

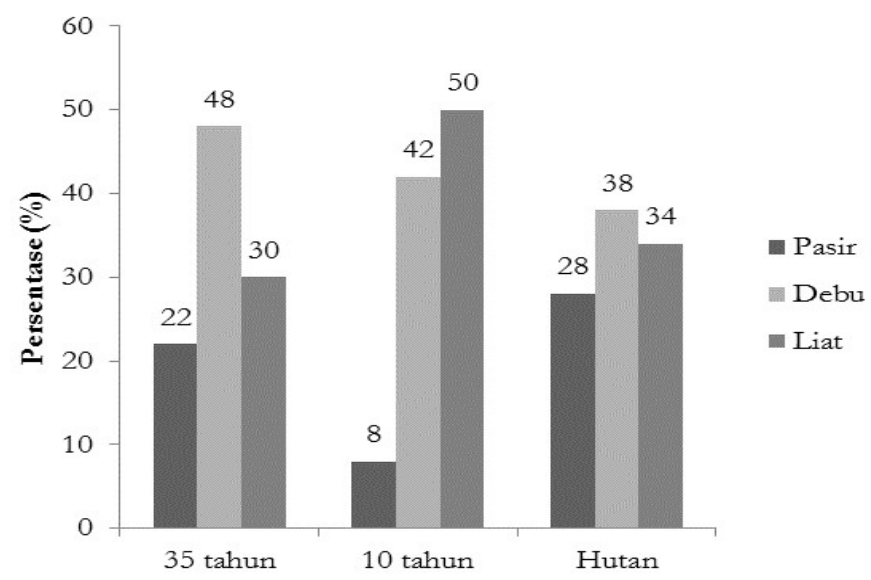

Gambar 1. Tekstur tanah pada perkebunan teh Kecamatan Gunung Talang, Kabupaten Solok.

Tabel 1. Berat volume dan total ruang pori tanah perkebunan teh Kecamatan Gunung Talang, Kabupaten Solok.

\begin{tabular}{|c|c|c|c|c|}
\hline \multirow[t]{2}{*}{ Kelerengan } & \multicolumn{2}{|c|}{35 tahun } & \multicolumn{2}{|c|}{10 tahun } \\
\hline & BV $\left(\mathrm{g} \mathrm{cm}^{-3}\right)$ & TRP (\%) & BV $\left(\mathrm{g} \mathrm{cm}^{-3}\right)$ & TRP (\%) \\
\hline $0-8 \%(\mathrm{~A})$ & $0,48 \mathrm{r}$ & $79,52 \mathrm{t}$ & $0,56 \mathrm{r}$ & $76,07 \mathrm{t}$ \\
\hline $8-15 \%$ (B) & $0,62 \mathrm{~s}$ & $74,07 \mathrm{~s}$ & $0,49 \mathrm{r}$ & $80,00 \mathrm{t}$ \\
\hline $15-25 \%(\mathrm{C})$ & $0,53 \mathrm{r}$ & $76,55 \mathrm{t}$ & $0,42 \mathrm{r}$ & $82,79 \mathrm{t}$ \\
\hline $25-45 \%$ (D) & $0,50 \mathrm{r}$ & $78,19 \mathrm{t}$ & $0,63 \mathrm{r}$ & $74,70 \mathrm{~s}$ \\
\hline$>45 \%(\mathrm{E})$ & $0,51 \mathrm{r}$ & $78,45 \mathrm{t}$ & $0,35 \mathrm{r}$ & $84,46 \mathrm{t}$ \\
\hline
\end{tabular}

Keterangan: $\mathrm{t}=$ tinggi, $\mathrm{s}=$ sedang, $\mathrm{r}=$ rendah $($ Balai Penelitian Tanah, 2009) 


\section{Jurnal Tanah dan Sumberdaya Lahan Vol 8 No 1: 75-81, 2021 e-ISSN:2549-9793, doi: 10.21776/ub.jts1.2021.008.1.10}

Nilai BV yang didapatkan memiliki kriteria yang rendah hingga sedang. Nilai BV ini berbanding terbalik dengan nilai total ruang pori yang memiliki kriteria sedang hingga tinggi. Perbedaan nilai berat volume tanah pada teh berumur 35 tahun dan 10 tahun tidak jauh berbeda, tetapi jika dibandingkan dengan nilai berat volume pada tanah hutan, tanah hutan memiliki nilai berat volume tanah yang berkriteria sedang dengan nilai $0,80 \mathrm{~g} \mathrm{~cm}^{-3}$. Lokasi penelitian berada pada lereng Gunung Talang yang secara fisiografis termasuk ke dalam sistem volkan. Aktivitas Gunung Talang yang tergolong salah satu gunung api aktif di Sumatera Barat telah menghasilkan bahan piroklastik sebagai sumber bahan induk tanah. Menurut Badan Pusat Statistik Kabupaten Solok (2018), jenis batuan yang dijumpai di Kabupaten Solok merupakan batuan gunung api yang berasal dari bahan induk andesit, dan batuan andesit akan menghasilkan tanah dengan porositas yang lebih tinggi sehingga ini juga akan menurunkan nilai BV dari tanah di daerah ini. Di samping bahan induk tanah, berat volume tanah juga sangat dipengaruhi oleh kandungan bahan organik tanah. Menurut Yulnafatmawita et al. (2014) nilai berat volume suatu tanah akan berbanding terbalik dengan nilai bahan organik tanah, sedangkan nilai total ruang pori tanah akan berbanding lurus dengan nilai bahan organik tanah. Lawenga et al. (2015) juga menambahkan semakin tinggi nilai bahan organik suatu tanah akan cenderung menurunkan nilai berat volume tanah karena kepadatan tanah yang berkurang sedangkan porositas tanah akan semakin meningkat.

\section{Bahan organik}

Nilai bahan organik yang didapatkan menunjukkan adanya hubungan positif antara B.O dan nilai indeks stabilitas agregat. Selain memperbaiki nilai stabilitas agregat tanah, bahan organik juga akan membantu dalam meningkatkan jumlah total ruang pori tanah. Sesuai dengan pendapat Widianto et al. (2015) pemberian bahan organik ke dalam tanah akan berdampak pada menurunnya berat isi tanah yang berarti meningkatnya porositas tanah dan semakin meningkatnya kemantapan agregat. Nilai bahan organik yang tinggi ini didapatkan dari hasil dekomposisi bahan organik dipermukaan tanah yang berasal dari bagian tubuh tanaman yang jatuh ke permukaan tanah selama proses pemangkasan hingga panen. Sesuai dengan pendapat Arsyad (2000) batang, ranting, dan daun yang berguguran di permukaan tanah menjadi sumber utama bahan organik di dalam tanah. Bahkan nilai bahan organik pada perkebunan teh lebih tinggi dari bahan organik hutan sekunder yang tergolong sedang dengan angka 3,66\%.

Tabel 2. Nilai bahan organik tanah pada perkebunan teh Kecamatan Gunung Talang, Kabupaten Solok.

\begin{tabular}{lcc}
\hline Kelerengan & \multicolumn{2}{c}{ Umur } \\
\cline { 2 - 3 } & 35 tahun & $\mathbf{1 0}$ tahun \\
\hline $0-8 \%(\mathrm{~A})$ & $16.99 \mathrm{t}$ & $15.54 \mathrm{t}$ \\
$8-15 \%(\mathrm{~B})$ & $13.47 \mathrm{t}$ & $11.29 \mathrm{t}$ \\
$15-25 \%(\mathrm{C})$ & $10.07 \mathrm{t}$ & $9.81 \mathrm{~s}$ \\
$25-45 \%(\mathrm{D})$ & $12.73 \mathrm{t}$ & $3.24 \mathrm{r}$ \\
$>45 \%(\mathrm{E})$ & $10.42 \mathrm{t}$ & $5.60 \mathrm{~s}$ \\
\hline
\end{tabular}

Keterangan: $\mathrm{t}=$ tinggi, $\mathrm{s}=$ sedang, $\mathrm{r}=$ rendah (Balai Penelitian Tanah, 2009)

Pada tanaman teh berumur 35 tahun, kandungan bahan organik tanah tergolong tinggi pada berbagai kelerengan. Ini sesuai dengan nilai indeks stabilitas agregat pada lahan teh berumur 35 tahun tergolong mantap dan sangat mantap. Ini membuktikan bahwa bahan organik membantu dalam memantapkan agregat tanah dan memperbaiki sifat fisika tanah. Tetapi nilai bahan organik tertinggi didapatkan pada lahan dengan kemiringan 0$8 \%$ senilai $16,99 \%$. Ini disebabkan karena tumpukan serasah di lereng 0-8\% lebih banyak bertahan dipermukaan tanah saat terjadi hujan karena tidak terjadi aliran permukaan.

Serasah yang telah terdekomposisi akan menjadi penyumbang bahan organik yang banyak bagi tanah permukaan. Semakin curam lereng seperti pada kelerengan 25-45\% dan $>45 \%$, nilai bahan organik semakin turun tetapi masih tergolong pada kriteria yang tinggi. Dapat terlihat dengan semakin curamnya lereng nilai bahan organik semakin rendah. Hal ini kemungkinan disebabkan oleh karena lahan yang miring tidak mampu menahan bahan organik yang lebih banyak di permukaannya, sehingga bahan organik akan jatuh dan menumpuk pada lahan datar dibagian bawah. Pada teh yang berumur 10 tahun nilai bahan 


\section{Jurnal Tanah dan Sumberdaya Lahan Vol 8 No 1: 75-81, 2021 \\ e-ISSN:2549-9793, doi: 10.21776/ub.jts1.2021.008.1.10}

organik tertinggi didapatkan pada lereng 0 - 8\% dengan nilai $15,54 \%$ dan seterusnya menurun hingga lereng $25-45 \%$. Nilai bahan organik terendah juga didapatkan pada teh berumur 10 tahun pada lereng $25-45 \%$ yaitu 3,24\%. Kemudian kembali naik pada kelerengan $45 \%$ dengan nilai 5.60\%.

\section{Indeks stabilitas agregat tanah}

Stabilitas agregat adalah salah satu sifat fisika tanah terpenting yang menjadi salah satu indikator dalam mengetahui keadaan kualitas tanah dan penentuan kemampuan tanah dalam menahan erosi. Tanah dengan nilai indeks stabilitas agregat yang tinggi akan lebih kuat dalam menahan daya rusak air hujan yang jatuh ke permukaan tanah, sehingga tanah ini berpotensi kecil untuk bencana longsor dan banjir. Seperti yang disampaikan oleh Li et al., (2018), bahwa mempertahankan nilai stabilitas agregat tanah yang tinggi merupakan hal yang sangat penting untuk menjaga produktivitas tanah dan meminimalisir erosi akibat dari tanah yang terdegradasi.

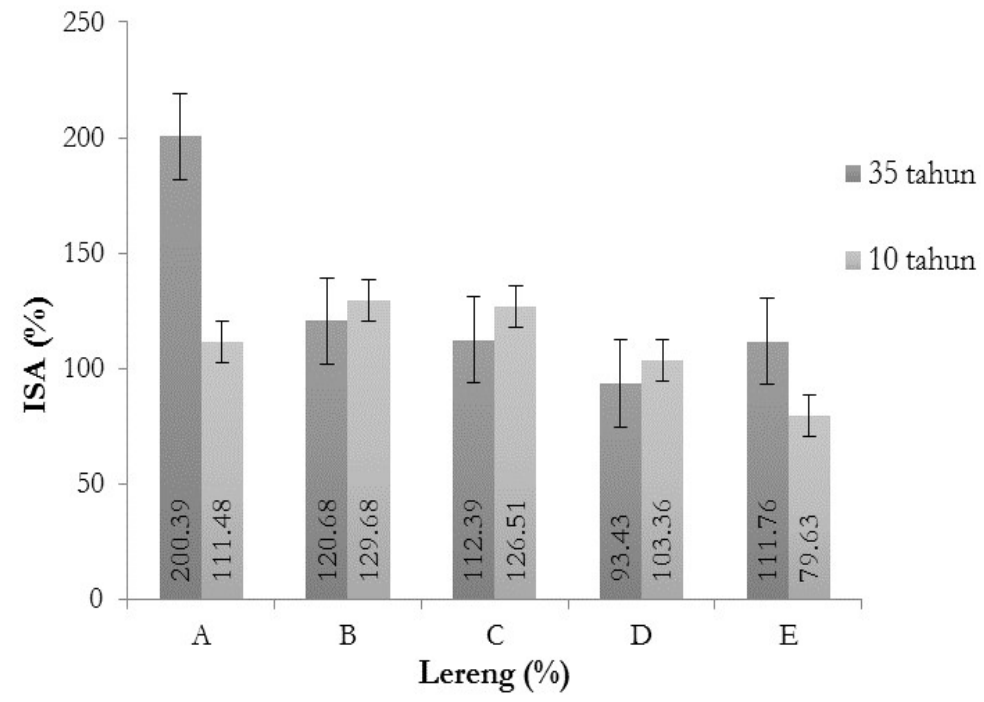

Gambar 2. Nilai indeks stabilitas agregat tanah pada perkebunan teh di Kecamatan Gunung Talang, Kabupaten Solok.

Nilai indeks stabilitas agregat (ISA) yang didapatkan dari hasil analisis di laboratorium disajikan pada Gambar 2. Secara umum nilai ISA yang didapatkan pada perkebunan teh tergolong mantap hingga sangat mantap menurut tabel kriteria Pusat Penelitian dan Pengembangan Tanah dan Agroklimat (2004). Nilai indeks stabilitas agregat tanah pada lahan teh berumur 35 tahun merupakan nilai tertinggi dari seluruh umur lahan. Ini disebabkan karena lahan yang berumur lebih panjang telah mendapatkan asupan bahan organik lebih banyak. Sehingga tanah cenderung lebih subur dibandingkan lahan yang berusia lebih muda. Sedangkan nilai ISA tanah terendah didapatkan pada teh berumur 10 tahun pada slope $>45 \%$ (E). Nilai ISA yang tinggi pada perkebunan teh berumur 35 tahun dipengaruhi oleh tingginya kandungan bahan organik yang ada di dalam tanah. Tanah yang kaya akan kandungan bahan organik, akan memiliki sifat fisika tanah yang baik juga, salah satunya yaitu kemantapan agregat yang baik. Dapat dilihat bahwa nilai stabilitas agregat perkebunan teh berumur 35 tahun dan 10 tahun pada daerah landai $0-8 \%$ (A) sangat jauh berbeda. Bahkan nilai ISA tanah pada kebun teh berumur 35 tahun lebih baik daripada nilai ISA hutan yaitu $120,65 \%$, walaupun memiliki kriteria yang sama yaitu Sangat Mantap.

Perbedaan nilai ISA tanah yang sangat signifikan pada kelerengan $0-8 \%$ (A) juga disebabkan oleh perakaran tanaman teh yang telah berkembang sangat pesat. Selain berfungsi sebagai penyerap air dan unsur hara, akar ternyata juga memberikan dampak yang sangat baik bagi keadaan fisik tanah yaitu membantu dalam memperbaiki kondisi fisik 


\section{Jurnal Tanah dan Sumberdaya Lahan Vol 8 No 1: 75-81, 2021 \\ e-ISSN:2549-9793, doi: 10.21776/ub.jts1.2021.008.1.10}

tanah baik melalui eksudat akar sebagai penyemen aggregat ataupun melalui pengikatan oleh akar tanaman. Arsyad (2006) melaporkan bahwa perakaran tanaman dapat memantapkan agregat tanah, karena rambut pada serabut akar dapat mengikat butir-butir tanah menjadi agregat. Terdapat korelasi yang positif antara nilai indeks stabilitas agregat dengan bahan organik pada lahan teh berumur 35 dan 10 tahun. Pada Gambar 3 terlihat bahwa bahan organik tanah memberikan pengaruh terhadap indeks stabilitas agregat sebanyak 21\%. Ini memperlihatkan bahwa bahan organik tanah mempengaruhi kemantapan agregat tanah.

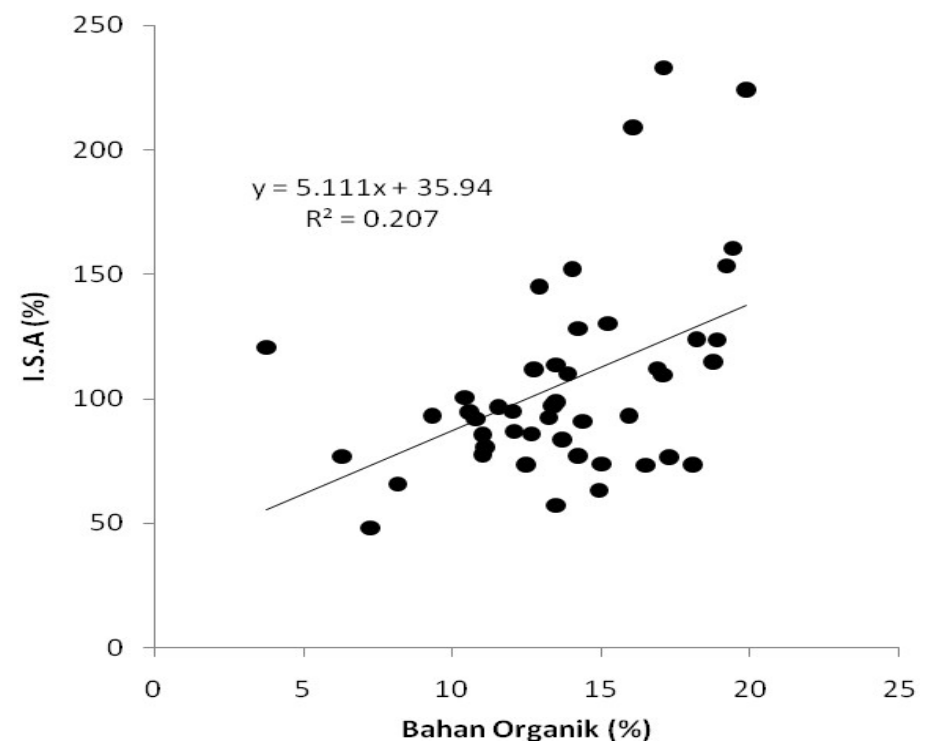

Gambar 3. Hubungan ISA dengan kandungan BO tanah pada perkebunan teh berumur 35 dan 10 tahun di Kecamatan Gunung Talang, Kabupaten Solok.

Seperti yang dikemukakan oleh Refliaty dan Marpaung (2010) bahan organik akan mengalami dekomposisi dan akan menghasilkan asam organik dan humus yang berfungsi sebagai agen pengikat butir tanah menjadi suatu kesatuan agregat yang utuh. Selain itu, proses perawatan dan kunjungan wisatawan yang menikmati pemandangan kebun teh setiap harinya membuat permukaan tanah di perkebunan menjadi semakin padat. Hal tersebut berdampak pada nilai BV dan TRP tanah serta akumulasi BO di tanah permukaan. Tanaman teh biasanya dipangkas setiap 5 tahun sekali, hal ini tentu akan sangat mempengaruhi nilai bahan organik pada permukaan tanah akibat residu tanaman yang menumpuk di permukaan tanah. Hanafiah (2012) melaporkan bahwa jaringan organik tanaman seperti ranting, akar, daun dan buah merupakan sumber primer bahan organik tanah, sedangkan jaringan organik dan kotoran fauna tanah merupakan sumber sekunder. Pada kondisi lahan yang cukup datar sangat kecil kemungkinan bahan organik hilang atau berpindah, sehingga jumlah bahan organik yang menumpuk dengan waktu dan membantu memantapkan agregat tanah. Tetapi pada kondisi slope yang besar kemungkinan bahan organik akan berpindah ke bahagian bawah. Penanaman teh yang telah mengikuti kaidah konservasi dengan mengikuti kontur sangat membantu dalam menjaga kondisi ini. Sehingga tidak banyak bahan organik yang terbuang saat terjadi hujan. Dengan kondisi curah hujan pada Kecamatan Gunung Talang yang tergolong tinggi (3087,5 mm tahun $\left.{ }^{-1}\right)$, tanah masih dapat mempertahankan kondisinya. Ini dapat dilihat pada baiknya keadaan stabilitas agregat dan jumlah bahan organik yang masih tinggi, tidak terlihat adanya bekas erosi yang terjadi walaupun berada pada slope yang sangat curam. 


\section{Jurnal Tanah dan Sumberdaya Lahan Vol 8 No 1: 75-81, 2021 e-ISSN:2549-9793, doi: 10.21776/ub.jts1.2021.008.1.10}

\section{Kesimpulan}

Nilai indeks stabilitas agregat pada perkebunan teh rakyat di Kecamatan Gunung Talang tergolong mantap hingga sangat mantap pada berbagai kelerengan dan umur tanaman. Nilai stabilitas agregat tanah tertinggi didapatkan pada lahan perkebunan teh berumur 35 tahun pada lereng $0-8 \%$, dan stabilitas agregat terendah didapatkan pada lahan perkebunan teh berumur 10 tahun di lereng $>45 \%$. Indeks stabilitas agregat tanah di perkebunan teh Gunung Talang tidak dipengaruhi oleh nilai BV, TRP, ataupun tekstur tanah, tetapi sangat dipengaruhi oleh kandungan bahan organik. Semakin tinggi nilai bahan organik maka nilai indeks stabilitas agregat tanah akan semakin mantap. Ini menunjukkan bahwa alih fungsi lahan hutan menjadi perkebunan teh di daerah ini tidak berdampak buruk bagi lingkungan di sekitar perkebunan teh.

\section{Daftar Pustaka}

Arsyad, S. 2006. Konservasi Tanah dan Air. Cetakan ketiga. IPB Press. Bogor.

BPPP (Badan Penelitian dan Pengembangan Perkebunan, Kementerian Pertanian). 2010. Budidaya dan Pasca Panen Teh. Badan Penelitian dan Pengembangan Pertanian. Bogor.

Badan Pusat Statistik Kabupaten Solok. 2018. Kecamatan Gunung Talang Dalam Angka., 2018. hal 89. https://solokkab.bps.go.id/ acc. 10 Desember 2019.

Balai Penelitian Tanah. 2009. Petunjuk teknis analisis kimia tanah, tanaman, air, dan pupuk. Badan Penelitian dan Pengembangan Pertanian Departemen Pertanian. Edisi Petunjuk Teknis 2. 246 hal.

Fitter, A.H. dan Hay, R.K.M. 1998. Fisiologi Lingkungan Tanaman. Terjemahan. Sri Andani dan Purbayanti. Gajah Mada University Press, Yogyakarta

Hanafiah, K.A. 2012. Dasar - Dasar Ilmu Tanah. PT Raja Grafindo Persada. Jakarta. 386 hal.

Junaedi, A. dan Safitri, I.A. 2018. Manajemen pemangkasan tanaman teh (Camellia sinensis (L.) O. Kuntze) di Unit Perkebunan Tambi, Jawa Tengah. Buletin Agrohorti 6(3) : 344 - 353.
Kurnia, U. 1996. Kajian Metode Rehabilitasi Lahan untuk Meningkatkan dan Melestarikan Produktivitas Tanah. Disertasi Fakultas Pasca Sarjana, IPB. Bogor.

Lawenga, F. F., Hasanah, U. dan Widjajanto, D. 2015. Pengaruh pemberian pupuk organik terhadap sifat fisika tanah dan hasil tanaman tomat (Lycopersicum esculentum Mill.) di Desa Bulupountu Kecamatan Sigi Biromaru Kabupaten Sigi. Agrotekbis 3(5) : 564-570

Li, T., Wang, S. and Zheng, Z. 2018. Effects of tea plantation age on soil aggregate-associated Cand $\mathrm{N}$-cycling enzyme activities in the hilly areas of Western Sichuan, China. Catena 171 : 145153.

Pusat Penelitian dan Pengembangan Tanah dan Agroklimat. 2004. Teknologi konservasi tanah pada lahan kering berlereng. Puslitbang Tanah dan Agroklimat. Bogor.

Refliaty, R. dan Marpaung, E.J. 2010. Kemantapan agregat Ultisol pada beberapa penggunaan lahan dan kemiringan Lereng. Jurnal Hidrolitan 1(2): 35-42.

Resman, A.S., Syamsul, S. dan Bambang, H.S. 2006. Kajian beberapa sifat kimia dan fisika inceptisol pada toposekuen lereng selatangunung merapi kabupaten sleman. Jurnal Ilmu Tanah dan Lingkungan 6(2):101-108.

Six, J., Elliot, E.T. and Paustian, K. 2000. Soil structure and soil organic matter: II. A normalized stability index and the effect of mineralogy. Soil Science Society of America Journal 64 : 1042-1049.

Wachjar, A. dan Rohmah, N. 2015. Pengelolaan pemangkasan tanaman teh (Camellia sinensis (L.) O. Kuntze) di Wonosobo. Buletin Agrohorti 3(1): 79-86

Widianto, Nuraini, Y. dan Utomo, B.Y. 2015. Kajian kemantapan agregat tanah pada pemberian beberapa jenis bahan organik di perkebunan kopi robusta. Jurnal Tanah dan Sumberdaya Lahan 2(1) : 111-117.

Yulnafatmawita., Asmar, dan Ramayani, A. 2007. Kajian Sifat Fisika 4 Tanah Utama di Sumatera Barat. Jurnal Solum 4(1): 80-89.

Yulnafatmawita., Detafiano, D., Afner, P. dan Adrinal. 2014. Dynamics of physical properties of ultisol under corn cultivation in wet tropical area. International Journal on Advanced Science, Engineering and Information Technology 4(5) : 11-15. 